\title{
Video Pembelajaran Animasi Berbasis Role Playing Tema Profesi pada Anak Usia Dini
}

\section{Ni Putu Dina Valentina ${ }^{1}$, I Wayan Sujana ${ }^{2}$}

1,2 Jurusan Pendidikan Dasar, Universitas Pendidikan Ganesha, Singaraja, Indonesia

\section{A R T I C L E I N F O}

Article history:

Received 27 Mei 2021

Revised 29 Mei 2021

Accepted 01 Juli 2021

Available online 25 Agustus 2021

Kata Kunci:

Video Pembelajaran animasi, Role Playing

\section{Keywords:}

Video Learning Animation, Role Playing

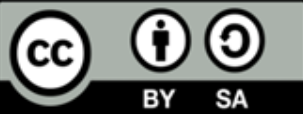

This is an open access article under the CC BY-SA license.

Copyright (@) 2021 by Author. Published by Universitas Pendidikan Ganesha.

\begin{abstract}
A B S T R A K
Penggunaan media pembelajaran yang masih manual dan metode konvensional membuat siswa merasa cepat bosan dalam belajar. Adanya pandemic covid-19 menyebabkan guru kesulitan dalam menyampaikan materi. Hal ini perlu adanya pengembangan khususnya media pembelajaran yang mampu meningkatkan motivasi dan semangat belajar siswa. Pengembangan video pembelajaran animasi berbasis Role Playing untuk meningkatkan motivasi dan ketertarikan belajar anak pada tema keluarga subtema profesi di TK. Pengembangan video pembelajaran berbasis Role Playing menggunakan metode pengembangan ADDIE yang terdiri dari 5 tahapan pengembangan. Tahapan-tahapan model ADDIE yaitu analyzed, design, development, implementation, evaluation. Subjek penelitian ini adalah ahli materi, ahli media dan ahli desain. Alpha testing oleh pengguna yaitu 3 siswa dan guru untuk mengetahui kelayakan dan respon siswa terhadap video pembelajaran berbasis role playing. Teknik analisis menggunakan analisis kualitatif dan kuantitatif. Hasil penilaian betha testing terhadap tingkat kelayakan materi sebesar $95 \%$ dengan kategori sangat baik, media sebesar $85 \%$ dengan kategori baik, desain $90 \%$ dengan kategori sangat baik. Alpha testing diperoleh rata-rata respon siswa uji perorangan sebesar $96 \%$. Maka, video pembelajaran berbasis Role Playing efektik digunakan sebagai panduan guru dalam memberikan materi pembelajaran, sehingga dapat meningkatkan motivasi dan semangat siswa.
\end{abstract}

\section{A BSTRACT}

The use of learning media that is still manual and conventional methods makes students feel bored quickly in learning. The COVID-19 pandemic has made it difficult for teachers to deliver material. This requires the development of learning media in particular that can increase students' motivation and enthusiasm for learning. Development of Role Playing-based animated learning videos to increase children's motivation and interest in learning on family themes, sub-themes of professions in kindergarten. The development of Role Playing-based learning videos uses the ADDIE development method which consists of 5 stages of development. The stages of the ADDIE model are analyzed, design, development, implementation, evaluation. The subjects of this research are material experts, media experts and design experts. Alpha testing by users, namely 3 students and teachers to determine the feasibility and student responses to role playing-based learning videos. The analysis technique uses qualitative and quantitative analysis. The results of the beta testing assessment on the feasibility level of the material are $95 \%$ in the very good category, the media is $85 \%$ in the good category, the design is $90 \%$ in the very good category. Alpha testing obtained an average individual test student response of $96 \%$. Thus, Role Playing-based learning videos are effectively used as a teacher's guide in providing learning materials, so that they can increase students' motivation and enthusiasm.

\section{PENDAHULUAN}

Pendidikan anak usia dini merupakan salah satu bentuk penyelenggaraan pendidikan yang menitikberatkan pada peletakan dasar kearah pertumbuhan dan perkembangan fisik (koordinasi motorik halus dan kasar), kecerdasan (daya pikir, daya cipta, kecerdasan emosi, kecerdasan spiritual), sosial emosional (sikap dan perilaku serta agama), bahasa, dan komunikasi, sesuai dengan keunikan dan tahap- 
tahap perkembangan yang dilalui anak usia dini (Agustin, 2020; Tanto et al., 2019). Lingkungan keluarga merupakan lingkungan pendidikan yang pertama dalam membentuk pribadi anak didik. Latihan secara fisik, mental, sosial bahasa serta keterampilan dalam lingkungan ini harus dibina sedini mungkin (Gustiana \& Puspita, 2020; Wahidah \& Suryadilaga, 2021). Anak usia dini memerlukan pendidikan yang sangat fundamental dan perlu mendapat perhatian yang memadai dari keluarga, masyarakat dan negara, karena pendidikan anak di jenajang berikutnya sangat dipengaruhi, bahkan ditentukan oleh berbagai stimulasi bermakna yang diberikan sejak usia dini (Cahya Ningrum et al., 2020; Subandji et al., 2020). Upaya pembinaan yang ditujukan kepada anak sejak lahir sampai dengan usia enam tahun yang dilakukan melalui pemberian rangsangan pendidikan untuk membantu pertumbuhan dan perkembangan jasmani dan rohani agar anak memiliki kesiapan dalam memasuki pendidikan lebih lanjut. Pendidikan anak usia dini (PAUD) adalah Jenjang pendidikan sebelum jenjang pendidikan dasar yang merupakan suatu upaya pembinaan yang yang ditujukan bagi anak sejak lahir sampai dengan enam tahun yang dilakukan melalui pemberian rangsangan pendidikan untuk membantu pertumbuhan dan perkembangan jasmani dan rohani agar anak memiliki kesiapan dalam memasuki pendidikan lebih lanjut, yang diselenggarakan pada jalur formal, nonformal dan informal (Junanto \& Kusna, 2018; Rakimahwati, 2012; Sufa \& Setiawan, 2018). Pendidikan anak usia dini sangat penting untuk diperhatikan khususnya di taman kanak-kanak. Taman kanak-kanak merupakan bentuk pendidikan formal yang memberi fasilitas bagi perkembangan anak untuk membantu pertumbuhan dan perkembangannya (Ruiyat et al., 2019; Zeptyani \& Wiarta, 2020).

Pentingnya pedidikan taman kanak-kanak karena akan menambah tumbuh kembangnya anak. Tujuan pendidikan anak usia dini yaitu meningkatkan daya cipta yang dimiliki anak dan memacu anak belajar bermacam-macam ilmu yang mencakup agama, sosial, emosi, bahasa, seni dan kemandirian sebab anak tengah berda pada periode pertumbuhan dan perkembangan kecerdasan yang pesat (Dista, 2020; Nurkolis \& Muhdi, 2020). Anak usia dini adalah individu yang sedang mengalami proses pertumbuhan dan perkembangan yang sangat pesat, bahkan dikatakan masa golden age dan diusia ini perkembangan anak sangat pesat. Anak usia dini memiliki rentang usia yang sangat berharga dibandingkan dengan usia-usia selanjutnya karena perkembangan kecerdasan yang paling baik. Di usia ini merupakan fase kehidupan yang unik, dan berada pada proses perubahan berupa pertumbuhan, perkembangan, pematangan, dan penyempurnaan, baik pada berbagai aspek jasmani maupun rohaninya berlangsung seumur hidup, bertahap, dan berkesinambungan(Suardi et al., 2019; Tanto et al., 2019). Dalam proses pembelajaran anak usia dini memerlukan peran penting guru dan orang tua dalam mengawasi perkembangan anak. Terlebih lagi saat ini dunia khususnya Indonesia menghadapi pandemic covid-19. Pemerintah Indonesia melalui Kementerian Pendidikan dan kebudayaan dan Kemeterian Agama RI menerapkan kebijakan belajar dan bekerja dari rumah (work from home) mulai pertengahan Maret 2020. Serangan COVID-19 telah mengubah metode dan budaya kerja pada banyak organisasi, fenomena kerja dari rumah sebagai upaya untuk mencegah penyebaran COVID-19 pada banyak negara di dunia berdampak pada produktifitas manusia (Mustajab et al., 2020; Sum \& Taran, 2020; Wardani \& Ayriza, 2020). Pandemic COVID-19 telah mengubah berbagai aspek kehidupan manusia saat ini, khususnya dalam dunia pendidikan. Ini mengharuskan semua elemen pendidikan untuk beradaptasi dan melanjutkan sisa semester (Herliandry, Devi ., 2020; Mufaziah \& Fauziah, 2020). Pendidikan anak usia dini pun tak lepas dari kebijakan pembelajaran daring. Hal ini tentunya membuat perubahan bentuk pembelajaran dari tatap muka menjadi pembelajaran jarak jauh, sehingga meminta guru untuk memutar otak mengajarkan anak dari rumah dengan bantuan orang tua tanpa meninggalkan esensi dan pencapaian perkembangan anak di rumah.

Nyatanya di lapangan pembelajaran ini sangat sulit karena orang tua mempunyai kesibukan tersendiri apalagi anak usia dini belum dibolehkan membawa handphone sendiri jadi anak harus menunggu orang tua pulang kerja baru bisa mengirim tugas, karena itu guru membutuhkan waktu yang lebih banyak dalam proses penilaian (Agustin, 2020; Wulandari \& Purwanta, 2021). Anak juga lebih sulit belajar dari rumah sehingga banyak orang tua yang mengeluhkan hal ini. Sedangkan tugas berbeda harus dikerjakan setiap harinya. Permasalahan yang banyak terjadi saat ini adalah guru dan siswa terbiasa menggunakan metode konvensional sehingga dapat mengakibatkan siswa menjadi kurang aktif dan hanya mendengarkan dari guru (Ketut et al., 2019; Lilawati, 2020). Saat di dalam kelas anak tidak semua perilaku anak merespon dan mendengarkan guru. Siswa yang antusias akan mendengarkan pembelajaran yang disampaikan guru(Zeptyani \& Wiarta, 2020). Hal ini menyatakan siswa yang tidak mendengarkan pembelajaran maka tidak akan memiliki antusias dalam belajar. Dengan pembelajaran daring pada masa pandemi tentunya yang berperan penting adalah orangtua, yaitu dukungan dari orangtua maupun lingkungan keluarga sangat diperlukan anak dalam menumbuhkan motivasi belajar pada masa pandemi ini (Cahyani et al., 2021). Rendahnya kompetensi guru dalam melaksanakan pembelajaran daring dan luring yang sesuai standard proses pada masa mewabahnya Covid-19 (Husain \& Kaharu, 2020; Malyana, 2020). 
Sedangkan tugas guru salah satunya adalah melaksanakan pembelajaran bermakna agar tercapai tujuan pembelajaran secara maksimal. Permasalahan lain juga disebabkan penggunaan model pembelajaran yang digunakan oleh guru dalam proses pembelajaran (Elan et al., 2017; Surya, 2017). Model konvensional yang selalu digunakan oleh guru saat ini tidak bisa diterapkan karena proses pembelajaran dilakukan secara daring. Permaslahan ini menjadi hambatan guru dalam menyampaikan materi pembelajaran kepada siswa anak usia dini. Salah satu Taman Kanak-Kanak yang mengalami kesulitan ini yaitu TK Kumara Loka Denpasar. TK Kumara Loka Denpasar merupakan salah satu Taman Kanak-Kanak yang memfasilitasi anak usia dini dalam belajar. Berdasarkan hasil wawancara dengan guru di Taman Kanak - Kanak Kumara Loka Denpasar mengatakan bahwa penggunaan media pembelajaran di TK kumara Loka Denpasar masih sangat terbatas yang masih berbasis konvensional seperti gambar, buku, dan puzzle sehingga tidak bisa digunakan dalam proses pembelajaran daring apalagi selama pandemic ini segala kegiatan dibatasi. Anak harus berdiam diri di rumah dalam waktu yang lama sehingga banyak anak merasa bosan sehingga guru harus memikirkan kegiatan supaya anak dapat berkegiatan walaupun hanya di dalam rumah saja. Apalagi di masa pandemi ini motivasi belajar anak sangat rendah terlihat pada saat penulis melakukan PPL, anak seperti tidak bersemangat untuk mengerjakan tugas yang telah diberikan oleh guru.

Solusi untuk mengatasi permasalah tersebut yaitu diperlukan media pembelajaran yang dapat membantu siswa dalam belajar sehingga siswa lebih mudah dalam memahami materi pelajaran. Siswa anak usia dini juga sangat memerlukan media pembelajaran karena melalui media ini siswa lebih tertarik dalam belajar jika terdapat media pembelajaran yang menarik (Purnamasari \& Wuryandani, 2019). Selain itu melalui media pembelajaran mempermudah guru dalam penyampaian materi pelajaran (Maqfiroh et al., 2020) (Darmayanti et al., 2017). Media pembelajaran sebagai alat bantu kegiatan belajar mengajar untuk menyampaikan pesan agar mudah diterima dan dapat mengaktifkan dan memotivasi siswa dalam belajar (Syukur \& Fallo, 2019; Yuangga \& Sunarsi, 2020). Penggunaan media pembelajaran interaktif dinilai lebih baik dibandingkan dengan ceramah dan menggunakan media konvensional karena siswa lebih tertarik dengan bentuk yang variatif dari animasi, segi pewarnaan dan juga tampilan. Visualisasi pembelajaran dengan animasi juga dapat meningkatkan konsentrasi dan fokus pada anak (Riyanto, 2017; Utomo et al., 2020). Media pembelajaran sudah dikembangkan oleh banyak orang, memiliki tampilan yang menarik, dan interaktif, namun sebagian besar media pembelajaran yang dikembangkan masih belum sesuai dengan karakteristik anak-anak dan belum mampu meningkatkan rasa ingin tahu anak khususnya pada profesi. Berdasarkan hal tersebut untuk mengatasi permasalahan di atas maka dikembangkan media video pembelajaran berbasis Role Playing yang dapat membuat siswa termotivasi dan tertarik dalam belajar sehingga berdampak pada hasil belajar siswa.

Temuan penelitian sebelumnya menyatakan video pembelajaran efektif dalam membantu proses pembelajaran (Wahyuningtyas \& Roziah, 2020). Melalui video pembelajaran ini anak-anak ditampilkan animasi, gambar, dan audio visual yang akan sangat membantu anak dalam fokus belajar guru juga lebih percaya diri dalam menyampaikan informasi. Penggunaan media pembelajaran berupa video pembelajaran dapat menghubungkan perkembangan kognitif emosional, dan psikomotorik siswa. Video dapat memberi guru lebih banyak fleksibilitas dan mempelajari prespektif dari siswa (Mayang Ayu Sunami \& Aslam, 2021; Taqiya et al., 2019). Video dapat dijadikan media pembelajaran yang lebih efektif (Dewi \& Rimpiati, 2016; Jundu et al., 2020). Penggunaan media pembelajaran berbasis video diminati anak, hasil belajarnya juga lebih baik setelah menggunakan video pembelajaran (Batubara \& Ariani, 2016). Kemampuan anak dalam kategori mengingat, memahami, mengaplikasikan, menganalisis, mengevaluasi dan mencipta dapat meningkat apabila diberikan inovasi pembelajaran berupa aktivitas pembelajaran mengamati berbantuan audiovisual (Jampel \& Puspita, 2017). Media video pembelajaran ini dikombinasikan dengan metode bermain peran (role playing). Video pembelajaran animasi bermain peran (role playing) adalah model yang pertama, dimana anak dibuat untuk mengikuti peran berbeda dalam hidupnya ke dalam satu situasi permasalahan kehidupan nyata, kedua bahwa bermain peran dapat mendorong murid mengekspresikan perasaannya dan melepaskannya di dalam pementasan, ketiga bahwa proses psikologis melibatkan sikap, nilai dan keyakinan serta mengarahkan pada kesadaran melalui keterlibatan spontan yang disertai analisis. Metode Role Playing dapat meningkatkan hasil belajar siswa mulai dari yang terendah 15\% sampai yang tertinggi 105\% dengan hasil tersebut menggambarkan bahwa di berbagai sekolah dasar yang berbeda tempat bahwa model Role Playing efektif (Sari, 2020).

Pada video pembelajaran animasi ini mengambil tema keluargaku dan subtema profesi. Pembelajaran tema profesi di Taman Kanak-Kanak lebih banyak memanfaatkan jenis media visual. Media visual hanya memberikan pembelajaran kepada anak berupa gambar-gambar yang tercetak pada buku atau lukisan. Saat ini anak lebih memiliki ketertarikan tinggi terhadap teknologi multimedia, sehingga perlu memanfaatkan hal tersebut dalam memberikan media pembelajaran yang menarik perhatian anak dan bersifat interaktif. Video pembelajaran interaktif mampu mengaktifkan siswa untuk belajar dengan 
motivasi yang tinggi karena ketertarikannya pada sistem multimedia yang mampu menyuguhkan tampilan teks, gambar, video, suara, dan animasi. Oleh karena itu, tujuan penelitian ini menciptakan video pembelajaran animasi berbasis Role Playing pengenalan macam-macam profesi pada anak usia dini. Video ini didesain untuk mengenalkan berbagai macam profesi kepada anak-anak. Materi yang ada adalah belajar profesi seperti dokter, guru, polisi, dan lain sebagainya sehingga melalui video ini anak akan diajak belajar dan bermain peran.

\section{METODE}

Model penelitian pengembangan yang penulis gunakan adalah model ADDIE. Model ini sering digunakan untuk menggambarkan pendekatan sistematis untuk pengembangan instruksional. Dalam penelitian ini dikembangkan media video pembelajaran animasi berbasis Role Playing pada kelompok B TK Kumara Loka Denpasar menggunakan model pengembangan ADDIE (Analysis, Design, Development, Implementation, Evaluations). Model ADDIE ini dipilih karena alur pengembangannya yang dirasa cocok dalam mengembangkan media video pembelajaran animasi berbasis role playing. Model ADDIE merupakan salah satu desain pembelajaran yang bersifat sistematik (Tegeh, 2014). Ada lima tahapan dalam model ADDIE dapat dilihat pada gambar 1

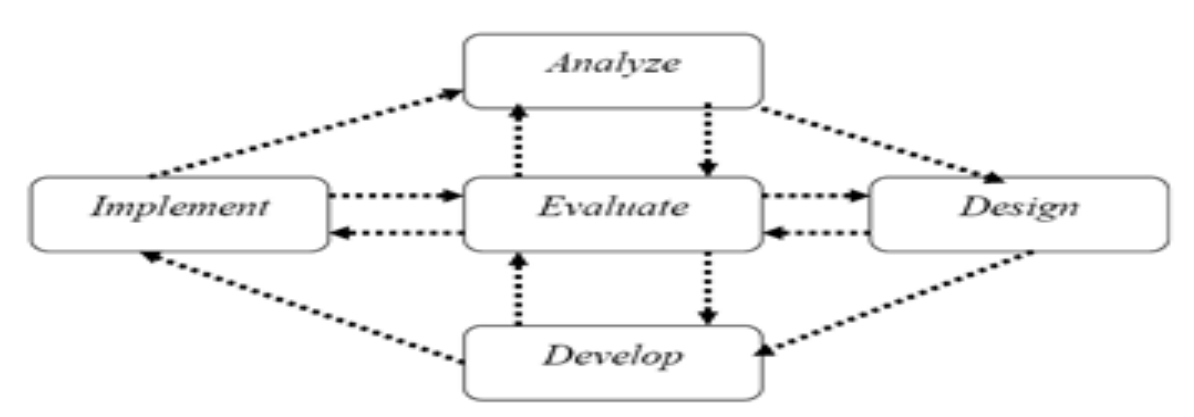

Gambar 1. Model ADDIE

Tahap I Analisis (Analyze). Tahap ini dilaksanakan dengan tujuan mengidentifikasi masalah, mengidentifikasi karakteristik sasaran dan kebutuhan yang diharapkan. Kebutuhan yang dituju seperti kompetensi sasaran dari penggunaan produk yang dihasilkan. Menurut Tegeh (2014), ada tiga pertanyaan yang harus dijawab dalam tahap analisis yaitu, 1) kompetensi apa saja yang harus dikuasai oleh peserta didik setelah menggunakan produk pengembangan, 2) kapabilitas belajar dari peserta didik baik itu pengetahuan, sikap maupun keterampilan, 3) karakteristik peserta didik yang akan menggunakan produk pengembangan ini. Ini akan berkaitan dengan keadaan peserta didik yang akan menjadi sasaran dalam penelitian. Keadaan yang dimaksud seperti; kemampuan awal siswa, kemampuan bahasa, gaya belajar, serta minat dan bakat. 4) Pertanyaan terakhir, sesuai dengan kompetensi yang dituntut dan karakteristik peserta didik, berkaitan dengan materi yang perlu dikembangkan. Tahap II Perencanaan (Design). Tujuan dari tahap perancangan adalah membuat spesifikasi secara terperinci mengenai arsitektur proyek, tampilan dan kebutuhan material proyek, serta gaya. Tahap ini menggunakan storyboard untuk menggambarkan rangkaian cerita atau deskripsi tiap scene sehingga dapat dimengerti oleh pengguna, dengan mencantumkan semua objek multimedia dan tautan ke scene lain. Pada tahap desain menurut Tegeh, dkk (2014) hendaknya dilakukan dengan kerangka acuan sebagai berikut yaitu: 1) pembelajaran yang dirancang untuk siswa; 2) kemampuan atau kompetensi yang ingin dikuasai 3) strategi pembelajaran yang digunakan untuk memahami keterampilan; 4) asesmen dan evaluasi yang dirancang. Tahap III Pengembangan (Development). Tahap yang dilaksanakan untuk mengembangkan produk dan memfasilitasi sumber-sumber belajar. Termasuk dalam memilih dan mengembangkan media pembelajaran yang cocok. Menurut Tegeh, dkk (2014) kegiatan tahap pengembangan antara lain : pencarian dan pengumpulan segala sumber atau referensi yang dibutuhkan untuk pengembangan materi, pembuatan bagan dan tabel-tabel pendukung, pembuatan gambar-gambar ilustrasi, pengetikan, pengaturan layout, penyusunan instrumen evaluasi, dan sebagainya.

Tahap IV Implementasi (Implementation). Tahap untuk mempersiapkan lingkungan belajar dan melibatkan siswa. Pada tahap implementasi (implementation) hasil pengembangan diterapkan dalam pembelajaran untuk mengetahui pengaruhnya terhadap kualitas pembelajaran yang meliputi keefektifan, kemenarikan, dan efisiensi pembelajaran. Tahap V Evaluasi (Evaluation). Tahap untuk menilai kualitas prosedur dan hasil pembelajaran ketika diterapkan maupun sesudah penerapan dan menganalisis data yang diperoleh dari peserta didik untuk mengetahui pendapat atau respon mengenai produk yang telah 
dibuat. Pada tahap ini dilakukan validitas untuk mengetahui kelayakan media video pembelajaran yaitu uji ahli materi, uji ahli media dan uji ahli desain. Selain itu juga dilakukan uji respon siswa untuk mengetahui ketertarikan siswa terhadap video pembelajaran. Metode pengumpulan data dalam penelitian ini melalui pelaksanaan evaluasi formatif yaitu data yang diperoleh dari hasil review ahli isi, ahli media dan ahli desain, serta data yang diperoleh dari uji coba perorangan. Data-data yang telah dikumpulkan tersebut kemudian dikelompokkan menjadi data kualitatif dan data kuantitatif yang diperoleh dengan menggunakan angket. Angket tersebut akan dibagikan kepada ahli isi, ahli media pembelajaran, ahli desain pembelajaran serta kepada siswa yang akan digunakan untuk hasil review siswa melalui uji coba perorangan. Adapun kisi-kisi instrumen kuesioner validitas ahli pada video pembelajaran animasi berbasis Role Playing beserta kisi-kisi instrumen untuk uji efektivitas dapat dilihat pada tabe 1,2,3, dan 4.

Tabel 1. Kisi-Kisi Instrumen Ahli Isi Pembelajaran

\begin{tabular}{|c|c|c|}
\hline No & Variabel & $\begin{array}{l}\text { Sub Variabel } \\
\end{array}$ \\
\hline 1 & Aspek Pendidikan & $\begin{array}{l}\text { a. Kesesuaian media dengan kompetensi } \\
\text { b. Isi produk media up to date } \\
\text { c. Sistematika dan kronologi materi jelas } \\
\text { d. Program reusable (sebagian atau seluruh program media dapat } \\
\text { dimanfaatkan kembali dalam pembelajaran untuk } \\
\text { mengembangkan pembelajaran lain }\end{array}$ \\
\hline 2 & Ketepatan Materi & $\begin{array}{l}\text { a. Tujuan pembelajaran mudah dipahami } \\
\text { b. Ketepatan dalam penggunaan bahasa } \\
\text { c. Kesesuaian gambar, animasi, audio,cerita, dan setting tempat } \\
\text { sesuai dengan konten pembelajaran } \\
\text { d. Bahasa yang digunakan mudah dipahami }\end{array}$ \\
\hline
\end{tabular}

Tabel 2. Kisi-Kisi Instrumen Ahli Desain Pembelajaran

\begin{tabular}{ccll}
\hline No & Variabel & & \multicolumn{1}{c}{ Sub Variabel } \\
\hline \multirow{2}{*}{1} & Aspek Desain & a. & Tampilan desain media \\
& & b. & Kualitas desain media \\
2 & Tampilan Desain Materi & a. & Kesesuaian desain dengan materi \\
& beterikatan terhdap & a. & Desain media sesuai dengan penyampaian materi \\
3 & Desain & b. & Menambah pengetahuan \\
\hline
\end{tabular}

Tabel 3. Kisi-Kisi Instrumen Ahli Media Pembelajaran

\begin{tabular}{|c|c|c|}
\hline No & Variabel & Sub Variabel \\
\hline 1 & Aspek Media & $\begin{array}{l}\text { a. Program Maintainable } \\
\text { b. Program usebilitas } \\
\text { c. Program Kontabilitas ( media pembelajaran dapat dijalankan diberbagai } \\
\text { hardware dan software yang ada } \\
\text { d. Program reusable (sebagian atau seluruh program media dapat } \\
\text { dimanfaatkan kembali dalam pembelajaran untuk mengembangkan } \\
\text { pembelajaran lain }\end{array}$ \\
\hline 2 & $\begin{array}{l}\text { Tampilan } \\
\text { Vidoe }\end{array}$ & $\begin{array}{l}\text { a. Kesesuaian dengan karakter siswa } \\
\text { b. Ketepatan dalam penggunaan bahasa } \\
\text { c. Kesesuaian animasi, video dan audio } \\
\text { d. Cerita menarik }\end{array}$ \\
\hline 3 & $\begin{array}{l}\text { Kualitas } \\
\text { Teknis, } \\
\text { Keefektifan } \\
\text { Video }\end{array}$ & $\begin{array}{l}\text { c. Kejelasan suara dan daya dukung musik } \\
\text { d. Produk tidak membosankan } \\
\text { e. Materi dalam media sesuai dengan tujuan pembelajaran }\end{array}$ \\
\hline
\end{tabular}

Tabel 4. Kisi-Kisi Instrumen Uji Perorangan

\begin{tabular}{|c|c|c|}
\hline No & Aspek & Indikator \\
\hline 1 & Desain Pesan & $\begin{array}{l}\text { a) Kemenarikan pembukaan video } \\
\text { b) Keterbacaan teks } \\
\text { c) Kejelasan gambar }\end{array}$ \\
\hline
\end{tabular}




\begin{tabular}{llll}
\hline No & Aspek & & \multicolumn{1}{c}{ Indikator } \\
\hline & & d) & Kejelasan suara \\
2 & Materi & e) & Kemudahan pemahaman materi \\
3 & Motivasi & f) & Kejelasan uraian materi \\
\hline
\end{tabular}

(Suartama, 2016)

Teknik Pengumpulan data pada penelitian ini melalui observasi, wawancara, dan studi kepustakaan. Instrumen yang digunakan dalam penelitian ini adalah kuesioner. Variabel yang akan dikaji dalam pengembangan adalah media video berbasis Role Playing di TK adalah unsur kelayakan. Definisi operasional dalam penelitian pengembangan ini adalah proses mengembangkan media yang dapat dipakai membantu peserta didik mengenali macam profesi dalam bentuk media video yang memenuhi unsur kelayakan, sehingga dapat membantu dalam proses pembelajaran mengenai jenis-jenis profesi di TK. Analisis data dalam penelitian pengembangan video jenis-jenis profesi terdiri analisis data kualitatif dan data persentase. Kemudian diaplikasikan untuk menganalisis data yang diperoleh dari angket tertutup dengan perhitungan skala likert dapat dilihat pada tabe 5 .

Tabel 5. Konversi Tingkat Pencapaian dengan Skala Likert (Skala 4)

\begin{tabular}{ccc}
\hline Nilai Angka & Nilai Huruf & Predikat \\
\hline 4 & A & Sangat Baik \\
3 & B & Baik \\
2 & C & Tidak Baik \\
1 & D & Sangat Tidak Baik \\
\hline
\end{tabular}

\section{HASIL DAN PEMBAHASAN}

Hasil

Rancang bangun pengembangan video pembelajaran berbasis Role Playing ini menggunakan model ADDIE. Media ini dirancang sesuai dengan tahap model ADDIE yang terdiri dari lima tahapan. Tahap pertama dari tahap ADDIE adalah tahap analisis (analyze), dilanjutkan dengan tahap merancang (design), tahap selanjutnya yaitu tahap pengembangan (development), dilanjutkan dengan tahap ke empat yaitu tahap implementasi (implementation), dan tahap yang kelima adalah tahap evaluasi (evaluation). Pertama, tahap analisis. Tahap ini dilakukan analisis kebutuhan analisis karakteristik siswa, analisis pembelajaran, dan analisis media. Tahap ini bertujuan untuk menganalisis kebutuhan, karakteristik, pembelajaran, dan analisis media. Hal tersebut dilakukan untuk mengetahui perlu tidaknya dilakukan sebuah pengembangan media pembelajaran. Berdasarkan hasil wawancara dengan guru di Taman Kanak - Kanak Kumara Loka Denpasar mengatakan bahwa penggunaan media pembelajaran di TK kumara Loka Denpasar masih sangat terbatas yang masih berbasis konvensional seperti gambar, buku, dan puzzle sehingga tidak bisa digunakan dalam proses pembelajaran daring apalagi selama pandemic ini segala kegiatan dibatasi. Anak harus berdiam diri di rumah dalam waktu yang lama sehingga banyak anak merasa bosan sehingga guru harus memikirkan kegiatan supaya anak dapat berkegiatan walaupun hanya di dalam rumah saja. Apalagi di masa pandemi ini motivasi belajar anak sangat rendah terlihat pada saat penulis melakukan PPL, anak seperti tidak bersemangat untuk mengerjakan tugas yang telah diberikan oleh guru.

Kedua, tahap desain. Secara garis besar video pembelajaran ini terdiri dari pembukaan, pengenalan karakter, dialog, penjelasan materi, dialog dan penutup. Video pembelajaran ini menggunakan perpaduan antara teks, gambar, animasi, dan musik dengan dubbing yang atraktif untuk membuat video menjadi lebih interaktif dan menarik. Berikut merupaan hasil dari video yang telah dikembangkan. Pada tampilan selanjutnya yaitu apersepsi yang ditunjukkan dengan tampilan seorang anak berupa karakter animasi menjelaskan apa saja yang ada pada video pembelajaran, selain itu juga mengajarkan sikap Ketuhanan Yang Maha Esa yaitu berdoa sebelum memulai pembelajaran. Tampilan selanjutnya yaitu percakapan seorang anak bertanya kepada ayah nya mengenai materi pembelajaran profesi. Untuk mempertegas materi profesi selanjutnya ditampilkan jenis-jenis profesi yang dijelaskan oleh ayah. Dalam video pembelajaran dijelaskan jenis-jenis profesi seperti pedagang, guru, presiden, masinis, polisi dan dokter. Di akhir materi, anak-anak diajarkan bermain peran dengan menampilkan contoh anak menjadi seorang dokter. Pada tampilan ini diperagakan bermain peran (role playing) sebagai dokter. Tujuan dari video tersebut yaitu untuk mengajarkan siswa dalam berinteraksi sebagai makhluk sosial dan siswa mampu memahami jenis profesi. 
Ketiga tahap pengembangan, Pada tahap pengembangan mulai dibuat media yang akan dikembangkan. Pada tahap ini dilaksanakan pengembangan media sesuai dengan rancangan yang sudah dibuat. Setelah produk dikembangkan, dilanjutkan dengan menguji coba produk yang terlebih dahulu dinilai oleh para ahli yang terdiri dari ahli materi, ahli media pembelajaran, dan uji praktisi. Tahap ini bertujuan untuk mengetahui kelayakan produk yang sudah dibuat. Hasil validasi yang dilakukan oleh ahli materi pembelajaran yaitu 95\% berada pada rentangan 90-100\% dengan kualifikasi "sangat baik". Yang dinilai dari uji ahli materi ini adalah aspek pendidikan, ketepatan materi, indikator, rpph, dan kompetensi dasar. Sehingga video pembelajaran berbasis Role Playing ini dari segi aspek materi pembelajaran layak untuk digunakan. Selanjutnya validasi oleh ahli media yang bertujuan untuk mendapatkan data penelitian, pendapat, dan saran terhadap media yang digunakan pada video pembelajaran yang telah dikembangkan. Pengujian dilakukan dengan pengoperasian video pembelajaran disertai penilaian menggunakan instrumen angket untuk menguji video pembelajaran. Melalui penilaian ahli media pembelajaran diperoleh nilai yaitu $85 \%$ berada pada rentangan 75-89\% dengan kualifikasi "baik". Selanjutnya dilakukan validasi ahli desain pembelajaran. Berdasarkan konversi skala 5, persentase yang diperoleh yaitu $90 \%$ berada pada rentangan 90-100\% dengan kualifikasi "sangat baik". Jadi video pembelajaran berbasis Role Playing layak untuk digunakan berdasarkan validasi oleh ahli materi pembelajaran, ahli media pembelajaran dan ahli desain pembelajaran. Dengan demikian video pembelajaran berbasis Role Playing memiliki peran yang sangat baik dan layak untuk digunakan dalam kegiatan pembelajaran khususnya pada tema keluarga subtema profesi. Data hasil uji tingkat kelayakan produk ditunjukkan pada Tabel 6.

Tabel 6. Hasil Uji Kelayakan Produk

\begin{tabular}{ll}
\hline Pengujian Ahli & Hasil Perhitungan \\
\hline Ahli Isi Materi & $95 \%$ \\
Ahli Media & $85 \%$ \\
Ahli Desain & $90 \%$ \\
\hline
\end{tabular}

Setelah melalui tahapan pengujian/review dari para ahli, selanjutnya dilakukan uji coba perorangan. Pada uji coba perorangan ini video pembelajaran berbasis Role Playing di uji coba oleh tiga orang siswa setiap siswa yang dijadikan responden diberikan instrumen angket penilaian produk video pembelajaran. Subjek dari uji coba perorangan adalah 3 orang siswa Kelompok B TK Kumara Loka Denpasar yang terdiri atas satu orang dengan prestasi belajar tinggi, satu orang dengan prestasi belajar sedang, dan satu orang dengan prestasi belajar rendah. Hasil penilaian uji coba perorangan terhadap video pembelajaran berbasis Role Playing ini dilakukan dengan menggunakan kuisioner yang diberikan kepada siswa. Pengisian kuisioner dipandu oleh penulis dikarenakan siswa belum maksimal bisa membaca. Pengisian kuisioner murni dilakukan oleh siswa tanpa adanya interpensi. Berdasarkan tabel konversi skala 5, persentase yang diperoleh yaitu 96,66\% berada pada rentangan 90-100\% dengan kualifikasi sangat baik dengan tanpa revisi sehingga produk video pembelajaran ini tidak perlu direvisi. Instrument pada uji coba perorangan ini memberikan beberapa masukan guna untuk menyempurnakan produk pengembangan video pembelajaran berbasis Role Playing ini.

Pengembangna video pembelajaran berbasis Role Playing melalui 5 tahap yaitu 1. Analyze; 2. Design; 3. Development; 4. implementation; 5. Evaluation. Pengembangan video pembelajaran berbasis Role Playing dilakukan pada tema keluarga dan subtema profesi untuk siswa Kelompok B TK Kumara Loka Denpasar. Pengembangan video pembelajaran berbasis Role Playing dalam pembuatannya menggunakan Software Wondersahre Filmora dan Plotagon Story. Proses pembuatan dilakasanakan secara bertahap dan untuk menghasilkan video pembelajaran yang layak. Pengembangan video pembelajaran berbasis Role Playing dimaksudkan untuk meningkatkan pemahaman dan konsentrasi siswa serta mempermudah proses belajar siswa di rumah. Pengembangan video pembelajaran berbasis Role Playing menggunakan animasi dengan tampilan yang menarik dalam penyampaian materi, hal ini bertujuan untuk menarik perhatian siswa dalam belajar. Melalui penilaian hasil uji ahli materi pembelajaran menyatakan bahwa video pembelajaran berbasis Role Playing yang dikembangkan sudah sesuai. Media Video pembelajaran berbasis Role Playing layak diterapkan dalam proses pembelajaran hal ini disebabkan oleh beberapa faktor yaitu sebagai berikut.

Pertama, video pembelajaran berbasis Role Playing dari segi media dan desain pembelajaran mendapatkan kualifikasi sangat baik dikarenakan dari segi penilaian ahli media dan desain pembelajaran, video pembelajaran berbasis Role Playing mampu memotivasi siswa dalam berkegiatan belajar. Pembelajaran yang baik adalah suatu proses kegiatan belajar yang mampu menciptakan kondisi yang positif bagi siswa dalam artian proses pembelajaran yang efektif dan menyenangkan serta mampu menumbuhkan motivasi siswa untuk belajar dalam mencapai hasil belajar yang optimal (Andriyani \& Suniasih, 2021; Fadillah \& Bilda, 2019; Vadia et al., 2020). Video pembelajaran memiliki kedudukan 
sebagai suplemen (tambahan) dalam proses pembelajaran (Hidayati et al., 2019; Yusnia, 2019). Artinya, media video pembelajaran yang dikembangkan layak dan efektif mampu meningkatkan pemahanan siswa serta dapat digunakan dalam proses pembelajaran. Berdasarkan penilaian tersebut video pembelajaran berbasis Role Playing yang telah dikembangkan dari segi media dan desain pembelajaran sudah sesuai dengan karakteristik siswa dengan tampilan menarik.

Kedua, video pembelajaran mampu meningkatkan pemahaman materi pada anak dan layak untuk digunakan berdasarkan pada hasil uji ahli. Keefektifan video pembelajaran berbasis Role Playing dapat dilihat dari hasil rerata uji coba perorangan sebesar $96,66 \%$. Hal ini berarti video pembelajaran yang dikembangkan efektif dan mampu meningkatkan motivasi anak dalam belajar. Video pembelajaran berbasis Role Playing ini mampu meningkatkan motivasi siswa dan semangat belajar siswa, dilihat dari komentar yang diberikan oleh siswa saat dilakukan uji coba produk (Sobri et al., 2020). Hal ini karena video pembelajaran berbasis Role Playing terdapat gambar yang menarik, animasi yang interaktif, penjelasan materi yang jelas, dan terdapat contoh bermain peran (role playing) yang mampu memotivasi siswa dalam belajar dan meningkatkan semangat siswa dalam meraih cita-citanya sesuai dengan profesi yang diinginkannya. Penggunaan model pembelajaran Role Playing berhasil membuat suasana pembelajaran semakin menarik, aktif, dan berhasil meningkatkan kemampuan akademik siswa (Nurgiansah et al., 2021). Adanya keefektifan model Role Playing setelah digunakan dalam proses pembelajaran (Kasanah et al., 2019; Murniviyanti et al., 2020). Dengan adanya video pembelajaran berbasis Role Playing dalam menunjang proses pembelajaran yang memberikan fasilitas kegiatan belajar siswa untuk mencari, mengolah, dan menemukan pengalaman belajar yang lebih bersifat konkret melalui keterlibatan aktivitas siswa dalam mencoba, melakukan, dan mengalami sendiri. Dengan demikian, pembelajaran tidak sekedar dilihat dari sisi produk, akan tetapi yang terpenting adalah proses. Video pembelajaran berbasis Role Playing merupakan pembelajaran yang memungkinkan siswa menerapkan dan mengikuti peran disetiap adegan yang ingin dilakukannya. Apa yang sedang diajarkan dengan mengacu pada masalah-masalah dunia nyata, sehingga pembelajaran akan menjadi lebih berarti dan menyenangkan. Dengan begitu siswa menjadi termotivasi untuk belajar dan siswa dapat meningkatkan hasil belajar.

Temuan penelitian ini diperkuat dengan penelitian sebelumnya menyatakan media video pembelajaran sangat efektif digunakan pada proses pembelajaran (Pamungkas et al., 2018; Suryana \& Hijriani, 2021). Penggunaan video pembelajaran animasi edukatif sangat efektif sebagai media untuk mengembangkan semangat dan motivasi siswa, hal ini ditinjau melalui kriteria pembelajaran video untuk anak, yaitu syarat ideal media pembelajaran video harus memenuhi beberapa kriteria antara lain kejelasan pesan, berdiri sendiri, akrab dengan anak, representasi isi, visualisasi atau kualitas gambar baik dapat digunakan klaisikal maupun individual (Miranda, 2019; Nurhayati et al., 2018). Kejelasan dan keterkaitan antara media pembelajaran dengan indikator, tujuan, dan materi, harus menjadi perhatian dan pertimbangan pengajar untuk memilih dan menggunakan media dalam proses pembelajaran di kelas sehingga media yang digunakan lebih efektif dan efisien untuk mencapai tujuan pembelajaran (Krissandi \& Rusmawan, 2015).Pengembangan video pebelajaran berbasis Role Playing ini sangat tepat dilakukan karena mampu meningkatkan potensi siswa dalam belajar menjadi lebih efektif. Hal serupa juga disampaikan oleh bahwa video pembelajaran membawa dampak positif bagi kegiatan belajar peserta didik seperti demontrasi materi, motivasi, tutorial, dan efektivitas waktu (Agustini \& Ngarti, 2020). Dari pembahasan diatas maka dapat dikatakan bahwa video pembelajaran berbasis Role Playing yang telah dikembangkan sudah valid sehingga dapat dipergunakan untuk siswa dalam kegiatan pembelajaran. Keterbatasan media ini yaitu media ini hanya diperuntukan untuk meningkatkan pemahaman materi profesi pada anak usia dini. Kelebihan media ini yaitu media yang dikembangkan berisikan gambar yang menarik sehingga meningkatkan motivasi belajar siswa. Selain itu pada media berisikan ilustrasi yang memudahkan siswa dalam memahami materi. Implikasi penelitian ini yaitu media yang telah dikembangkan dapat digunakan oleh guru dalam proses pembelajaran sehingga dapat meningkatkan pemahaman pada anak usia dini. Selain itu, media ini juga dapat meningkatkan motivasi dan menciptakan suasana belajar pada anak usia dini.

\section{SIMPULAN}

Video pembelajaran berbasis Role Playing yang telah dikembangkan sudah valid sehingga dapat dipergunakan untuk siswa dalam kegiatan pembelajaran. Video pembelajaran berbasis Role Playing mampu meningkatkakn pemahaman siswa dalam belajar. Video pembelajaran dinilai cukup menyita perhatian anak dalam belajar dari rumah, sehingga anak-anak tertarik atau munculnya motivasi belajar, video animasi yang dikembangan telah mampu menarik perhatian anak membuat anak serius dan menyenangi proses pembelajaran, serta mampu mencapai tujuan pembelajaran yaitu membuat anak 
mengetahui ada banyak jenis-jenis profesi, mempraktekkan dan bermain peran salah satu profesi, menghargai setia profesi, dan menjaga toleransi.

\section{DAFTAR RUJUKAN}

Agustin, M. (2020). Tipikal Kendala Guru PAUD dalam Mengajar pada Masa Pandemi Covid 19 dan Implikasinya. Jurnal Obsesi: Jurnal Pendidikan Anak Usia Dini, 5(1), 334-345. https://doi.org/10.31004/obsesi.v5i1.598.

Agustini, K., \& Ngarti, J. G. (2020). Pengembangan Video Pembelajaran Untuk Meningkatkan Motivasi Belajar Siswa Menggunakan Model R \& D. Jurnal Ilmiah Pendidikan Dan Pembelajaran, 4(2), 6278. https://doi.org/10.23887/jipp.v4i1.18403.

Andriyani, N. L., \& Suniasih, N. W. (2021). Development Of Learning Videos Based On Problem-Solving Characteristics Of Animals And Their Habitats Contain in Science Subjects On 6th-Grade. Journal of Education, 5(1), 37-47. https://doi.org/10.23887/jet.v5i1.32314.

Batubara, H. H., \& Ariani, D. N. (2016). Pemanfaatan Video sebagai Media Pembelajaran Matematika SD/MI. Muallimuna: Jurnal Madrasah Ibtidaiyah, 2(1), 47. https://doi.org/10.31602/muallimuna.v2i1.741.

Cahya Ningrum, E. S., Christianti, M., Maryatun, I. B., \& Cholimah, N. (2020). Pelatihan penggunaan buku panduan pembuatan dan pelaksanaan pembelajaran di taman lalu lintas untuk guru taman kanakkanak. Jurnal Pendidikan Anak, 9(1), 1-8. https://doi.org/10.21831/jpa.v9i1.31395.

Cahyani, A. D., Yulianingsih, W., \& Roesminingsih, M. (2021). Sinergi antara Orang Tua dan Pendidik dalam Pendampingan Belajar Anak selama Pandemi Covid-19. Jurnal Obsesi, 6(2), 1054 - 1069. https://doi.org/10.31004/obsesi.v6i2.1130.

Darmayanti, P., Tegeh, I. M., \& Ujianti, R. (2017). Efektivitas Metode Bercerita Dengan Media Boneka Wayang Terhadap Kemampuan Bercakap-Cakap Anak Kelompok B Di Tk Widya Sesana Sangsit 2016/2017. E-Journal Pendidikan Anak Usia Dini, 5(3), 336-347. https://doi.org/10.23887/paud.v5i1.11557.

Dewi, L. M. I., \& Rimpiati, N. L. (2016). Efektivitas Penggunaan Media Pembelajaran Video Interaktif Dengan Seting Diskusi Kelompok Kecil Untuk Meningkatkan Keterampilan Berpikir Kritis Pada Anak Usia Dini. Jepun, 31-46. http://jurnal.undhirabali.ac.id/index.php/Jepun/article/view/78.

Dista, F. N. (2020). Manajemen Pendirian Taman Kanak-kanak (Studi Kasus di Tk Fastrack Funschool Yogyakarta). Jurnal Pendidikan Anak Usia Dini Undiksha, 8(2), 101-111. https: //doi.org/10.23887/paud.v8i2.22582.

Elan, E., Muiz L, D. A., \& Feranis, F. (2017). Penggunaan Media Puzzle untuk Meningkatkan Kemampuan Mengenal Bentuk Geometri. Jurnal Paud Agapedia, 1(1), 70. https://doi.org/10.17509/jpa.v1i1.7168.

Fadillah, A., \& Bilda, W. (2019). Pengembangan video pembelajaran matematika berbatuan aplikasi sparkoll videoscribe. Jurnal Gantang, 4(2), 177-182. https://doi.org/10.31629/jg.v4i2.1369.

Gustiana, A. D., \& Puspita, R. D. (2020). The Effect of Educative Games on the Physical Fitness of Kindergarten Children. Jurnal Pendidikan Jasmani Dan Olahraga, 5(2), 149 - 154. https://doi.org/10.17509/jpjo.v5i2.24518.

Herliandry, Devi ., N. M. E. S. H. K. (2020). Pembelajaran Pada Masa Pandemi Covid-19. Jurnal Pendidikan Teknologi, 22(1), 65-69. https://doi.org/10. 21009/jtp.v22i1.15286.

Hidayati, A., Adi, E., \& Praherdhiono, H. (2019). Bangan Media Video Pembelajaran Untuk Meningkatkan Pemahaman Materi Gaya Kelas Iv Di Sdn Sukoiber 1 Jombang. JINOTEP OJurnal Inovasi Dan Teknologi Pembelajaran) Kajian Dan Riset Dalam Teknologi Pembelajaran, 6(1), 45-50. https: //doi.org/10.17977/um031v6i12019p045.

Husain, R., \& Kaharu, A. (2020). Menghadapi Era Abad 21: Tantangan Guru Pendidikan Anak Usia Dini di Kabupaten Bone Bolango. Jurnal Obsesi: Jurnal Pendidikan Anak Usia Dini, 5(1), 85-92. https://doi.org/10.31004/obsesi.v5i1.527.

Jampel, I. N., \& Puspita, K. R. (2017). Peningkatan Hasil Belajar Siswa Sekolah Dasar Melalui Aktivitas Pembelajaran Mengamati Berbantuan Audiovisual. International Journal of Elementary Education, 1(3), 197. https://doi.org/10.23887/ijee.v1i3.10156.

Junanto, S., \& Kusna, N. A. A. (2018). Evaluasi Program Pembelajaran di PAUD Inklusi dengan Model Context, Input, Process, and Product (CIPP). Inklusi, 5(2), 179. https://doi.org/10.14421/ijds.050202.

Jundu, R., Nendi, F., Kurnila, V. S., Mulu, H., Ningsi, G. P., \& Ali, F. A. (2020). Pengembangan Video Pembelajaran Ipa Berbasis Kontekstual Di Manggarai Untuk Belajar Siswa Pada Masa Pandemic 
Covid-19. LENSA (Lentera Sains): Jurnal Pendidikan IPA, 10(2), 63-73. https://doi.org/10.24929/lensa.v10i2.112.

Kasanah, S. A., Damayani, A. T., \& Rofian, R. (2019). Keefektifan Model Pembelajaran Role Playing Berbantu Media Multiply Cards terhadap Hasil Belajar Siswa. Jurnal Ilmiah Sekolah Dasar, 3(4), 529. https://doi.org/10.23887/jisd.v3i4.22308.

Ketut, N., Suastariyani, N., \& Tirtayani, L. A. (2019). Survei Persepsi Orang Tua Mengenai Program Paud Inklusi. Jurnal Pendidikan Anak Usia Dini Undiksha, 8(2), 80-90. https://doi.org/10.23887/paud.v8i2.25156.

Krissandi, A. D. S., \& Rusmawan, R. (2015). Kendala Guru Sekolah Dasar Dalam Implementasi Kurikulum 2013. Jurnal Cakrawala Pendidikan, 3(3), 457-467. https://doi.org/10.21831/cp.v3i3.7409.

Lilawati, A. (2020). Peran Orang Tua dalam Mendukung Kegiatan Pembelajaran di Rumah pada Masa Pandemi. Jurnal Obsesi: Jurnal Pendidikan Anak Usia Dini, 5(1), 549. https://doi.org/10.31004/obsesi.v5i1.630.

Malyana, A. (2020). Pelaksanaan Pembelajaran Daring Dan Luring Dengan Metode Bimbingan Berkelanjutan Pada Guru Sekolah Dasar Di Teluk Betung Utara Bandar Lampung. Pedagogia: Jurnal Ilmiah Pendidikan Dasar Indonesia, 2(1), 67-76. https://doi.org/10.52217/pedagogia.v2i1.640.

Maqfiroh, D. N. M., Khutobah, K., \& Budyawati, L. P. I. (2020). Pengembangan Media Motif (Monopoli Edukatif) Dalam Pembelajaran Berbasis Multiple Intelligence Pada Anak Tk Kelompok B. Cakrawala Dini: Jurnal Pendidikan Anak Usia Dini, 11(1), 65-74. https://doi.org/10.17509/cd.v11i1.24230.

Mayang Ayu Sunami, \& Aslam. (2021). Pengaruh Penggunaan Media Pembelajaran Video Animasi Berbasis Zoom Meeting terhadap Minat dan Hasil Belajar IPA Siswa Sekolah Dasar. Jurnal Basicedu, 5(4), 19. https://doi.org/10.31004/basicedu.v5i4.1129.

Miranda, D. (2019). Pengembangan Video Animasi Berbasis Karakter Cinta Tanah Air Untuk Anak Usia Dini. Jurnal Visi Ilmu Pendidikan, 11(2), 12. https://doi.org/10.26418/jvip.v11i2.32565.

Mufaziah, E., \& Fauziah, P. (2020). Kendala Orang Tua dalam Mendidik Anak Usia Dini pada Saat Pandemi Covid 19. Jurnal Obsesi: Jurnal Pendidikan Anak Usia Dini, 5(2), 1045-1051. https://doi.org/10.31004/obsesi.v5i2.746.

Murniviyanti, L., Shaikh, M., \& Syandri, G. (2020). The Effectiveness of Role Playing Model on Upgrading Students' Skill of Appreciation. International Journal of EducatioMurniviyanti, L., Shaikh, M., \& Syandri, G. (2020). The Effectiveness of Role Playing Model on Upgrading Students' Skill of Appreciation. International Journal of Educational Review, 2(1), 106-110. Https://Doi.Org/Https://, 2(1), 106-110. https://doi.org/10.33369/ijer.v2i1.10666.

Mustajab, D., Bauw, A., Rasyid, A., Irawan, A., Akbar, M. A., \& Hamid, M. A. (2020). Working From Home Phenomenon As an Effort to Prevent COVID-19 Attacks and Its Impacts on Work Productivity. TIJAB (The International Journal of Applied Business), 4(1), 13. https://doi.org/10.20473/tijab.v4.i1.2020.13-21.

Nurgiansah, T. H., Hendri, H., \& Khoerudin, C. M. (2021). Role Playing dalam Pembelajaran Pendidikan Pancasila Dan Kewarganegaraan. Jurnal Kewarganegaraan, 18(1), 56. https://doi.org/10.24114/jk.v18i1.22597.

Nurhayati, I., Khumaedi, M., \& Yudiono, H. (2018). The Effectiveness of the Use of Video Media on Learning on the Competence of Scalp and Hair Care of Vocational High School Students of Beauty Department. Journal of Vocational and Career Education, 3(1), 66-72. https://doi.org/10.15294/jvce.v3i1.15388.

Nurkolis, N., \& Muhdi, M. (2020). Keefektivan Kebijakan E-Learning berbasis Sosial Media pada PAUD di Masa Pandemi Covid-19. Jurnal Obsesi: Jurnal Pendidikan Anak Usia Dini, 5(1), 212. https://doi.org/10.31004/obsesi.v5i1.535.

Pamungkas, A. S., Ihsanudin, I., Novaliyosi, N., \& Yandari, I. A. V. (2018). Video Pembelajaran Berbasis Sparkol Videoscribe: Inovasi Pada Perkuliahan Sejarah Matematika. Prima: Jurnal Pendidikan Matematika, 2(2), 127. https://doi.org/10.31000/prima.v2i2.705.

Purnamasari, Y. M., \& Wuryandani, W. (2019). Media Pembelajaran Big Book Berbasis Cerita Rakyat untuk Meningkatkan Karakter Toleransi pada Anak Usia Dini. Jurnal Obsesi : Jurnal Pendidikan Anak Usia Dini, 4(1), 90. https://doi.org/10.31004/obsesi.v4i1.273.

Rakimahwati, Y. (2012). Upaya Meningkatkan Perkembangan Moral Anak Usia Dini Melalui Mendongeng Di Tk Dharmawanita Improving the Moral Development of Early Age Children. Ilmiah Visi P2TK PAUD dex.php/jiv/article/download/2675/2025+\&cd=3\&hl=id\&ct=clnk\&gl=id. 
Riyanto, W. D. (2017). The Effectiveness of Interactive Multimedia in Mathematic Learning. (Utilizing Power Points for Students with Learning Disability). 1(1), 55-63. https://doi.org/10.20961/ijpte.v1i1.8400.

Ruiyat, S. A., Yufiarti, Y., \& Karnadi, K. (2019). Peningkatan Keterampilan Berbicara dengan Bercerita Menggunakan Komik Elektronik Tematik. Jurnal Obsesi : Jurnal Pendidikan Anak Usia Dini, 3(2), 518. https://doi.org/10.31004/obsesi.v3i2.256.

Sari, R. K. (2020). Efektivitas Penggunaan Model Pembelajaran Role Playing Terhadap Ketrampilan Berbicara Pada Bahasa Indonesia Tingkat Sd. Jurnal Pendidikan Dan Konseling (JPDK), 2(1), 61-67. https://doi.org/10.31004/jpdk.v1i2.582.

Sobri, M., Nursaptini, N., \& Novitasari, S. (2020). Mewujudkan Kemandirian Belajar Melalui Pembelajaran Berbasis Daring Diperguruan Tinggi Pada Era Industri 4.0. Jurnal Pendidikan Glasser, 4(1), 64. https://doi.org/10.32529/glasser.v4i1.373.

Suardi, I. P., Ramadhan, S., \& Asri, Y. (2019). Pemerolehan Bahasa Pertama pada Anak Usia Dini. Jurnal Obsesi : Jurnal Pendidikan Anak Usia Dini, 3(1), 265. https://doi.org/10.31004/obsesi.v3i1.160.

Suartama, I. K. (2016). Evaluasi dan Kriteria Kualitas Multimedia Pembelajaran. Universitas Pendidikan Ganesha.

Subandji, S., Shofa, M. F., \& Syamsiyati, R. N. (2020). Analisis kompetensi pendidik PAUD pada alumni program studi PIAUD FIT IAIN Surakarta. Jurnal Pendidikan Anak, 9(1), 9-19. https://doi.org/10.21831/jpa.v9i1.30651.

Sufa, F. F., \& Setiawan, M. H. (2018). Optimalisasi Peran Orangtua Dalam Mengembangkan Potensi PAUD. ADIWIDYA, 2(2), 289-298. https://doi.org/10.33061/awpm.v2i2.2521.

Sum, T. A., \& Taran, E. G. M. (2020). Kompetensi Pedagogik Guru PAUD dalam Perencanaan dan Pelaksanaan Pembelajaran. Jurnal Obsesi: Jurnal Pendidikan Anak Usia Dini, 4(2), 543. https://doi.org/10.31004/obsesi.v4i2.287.

Surya, Y. F. (2017). Penggunaan Model Pembelajaran Pendidikan Karakter Abad 21 pada Anak Usia Dini. Jurnal Obsesi: Jurnal Pendidikan Anak Usia Dini, 1(1), 52-61. https://doi.org/10.31004/obsesi.v1i1.30.

Suryana, D., \& Hijriani, A. (2021). Pengembangan Media Video Pembelajaran Tematik Anak Usia Dini 5-6 Tahun Berbasis Kearifan Lokal. Jurnal Obsesi: Jurnal Pendidikan Anak Usia Dini, 6(2), 1077-1094. https://doi.org/10.31004/obsesi.v6i2.1413.

Syukur, A., \& Fallo, Y. T. (2019). Peningkatan Kemampuan Anak dalam Mengenal Konsep Bilangan Melalui Penggunaan Media Pembelajaran Berbasis Alam. Jurnal PG-PAUD Trunojoyo : Jurnal Pendidikan Dan Pembelajaran Anak Usia Dini, 6(1), 1-11. https://doi.org/10.21107/pgpaudtrunojoyo.v6i1.5365.

Tanto, O. D., Hapidin, H., \& Supena, A. (2019). Penanaman Karakter Anak Usia Dini dalam Kesenian Tradisional Tatah Sungging. Jurnal Obsesi : Jurnal Pendidikan Anak Usia Dini, 3(2), 337-345. https://doi.org/10.31004/obsesi.v3i2.192.

Taqiya, Nuroso, \& Reffiane. (2019). Pengaruh Model Pembelajaran Terpadu Tipe Connected Berbantu Media Video Animasi. Mimbar PGSD Undiksha, 7(3), 289-295. https://doi.org/10.23887/jjpgsd.v7i3.19492.

Tegeh, I. M. (2014). Model Penelitian Pengembangan. Graha Ilmu.

Utomo, A. P., Amalia, T. R., Iqbal, M., \& Narulita, E. (2020). Android-based comic of biotechnology for senior high school students. International Journal of Scientific and Technology Research, 9(3), 4143-4150.

Vadia, P., Riandini, A., Sudatha, I. G. W., \& Parmiti, D. P. (2020). Korelasi antara Kecerdasan Emosional dan Motivasi Belajar dengan Hasil Belajar PPKn. Jurnal Mimbar PGSD Undiksha, 8(3), 468-478. https://doi.org/10.23887/jjpgsd.v8i3.26072.

Wahidah, A. F. N., \& Suryadilaga, M. A. (2021). Urgensi Pendidikan Anak Usia Dini Dalam Perspektif Hadits di Masa Pandemi Coronavirus. JECED : Journal of Early Childhood Education and Development, 3(1),1-14. https://doi.org/10.15642/jeced.v3i1.601.

Wahyuningtyas, D. P., \& Roziah, R. (2020). Pengembangan media pembelajaran berbasis sensory carpet untuk pemahaman panca indera anak usia 1-2 tahun. Jurnal Perkembangan Dan Pendidikan Anak Usia Dini, 1(2), 119-132. https://doi.org/10.18860/preschool.v1i2.9151.

Wardani, A., \& Ayriza, Y. (2020). Analisis Kendala Orang Tua dalam Mendampingi Anak Belajar di Rumah Pada Masa Pandemi Covid-19. Jurnal Obsesi: Jurnal Pendidikan Anak Usia Dini, 5(1), 772. https://doi.org/10.31004/obsesi.v5i1.705.

Wulandari, H., \& Purwanta, E. (2021). Pendidikan Anak Usia Dini Pencapaian Perkembangan Anak Usia Dini di TK selama Pembelajaran Daring saat Pandemi Covid-19. Jurnal Obsesi : Jurnal Pendidikan Anak Usia Dini, 5(1), 452-462. https://doi.org/10.31004/obsesi.v5i1.626.

Yuangga, K. D., \& Sunarsi, D. (2020). Pengembangan Media Dan Strategi Pembelajaran Untuk Mengatasi 
Permasalahan Pembelajaran Jarak Jauh Di Pandemi Covid- 19. Jurnal Guru Kita, 4(3), 51-58. https://doi.org/10.24114/jgk.v4i3.19472.

Yusnia, Y. (2019). Penggunaan Media Video Scribe Dalam Pembelajaran Literasi Sains Untuk Mahasiswa PGPAUD. Cakrawala Dini: Jurnal Pendidikan Anak Usia Dini, 10(1), 71-75. https://doi.org/10.17509/cd.v10i1.17436.

Zeptyani, P. A. D., \& Wiarta, I. W. (2020). Pengaruh Project-Based Outdoor Learning Activity Menggunakan Media Audio Visual Terhadap Perilaku Belajar Anak Usia Dini. Jurnal Pendidikan Anak Usia Dini Undiksha, 8(2), 69-79. https://doi.org/10.23887/paud.v8i2.24740. 